Available online at https://jurnal.stmikroyal.ac.id/index.php/jurdimas

\title{
PELATIHAN PENYUSUNAN PTK BAGI GURU SD DI KECAMATAN SECANG
}

\author{
Athia Fidian*1, Agrissto Bintang Aji Pradana ${ }^{2}$ \\ ${ }^{1}$ Fikes, Universitas Muhammadiyah Magelang \\ ${ }^{2}$ PGSD, Universitas Muhammadiyah Magelang \\ email:*athiafidian@ummgl.ac.id
}

\begin{abstract}
The 2009 Permenpan-RB on Sustainable Professional Development is not only aimed at PNS teachers but teachers in general. Members of the GTT-PTT Honorary Staff Forum at Secang District have a strong desire to be able to arrange the classroom action research (CAR). However, this desire is constrained by the limited opportunities given to them attending CAR training. Most of them do not have enough knowledge about CAR preparation. In addition to being unfamiliar with research methods, they also lack knowledge of how to plan and compile their reports. Seeing this problem, this dedication activity became a concrete effort to help teachers, especially members of the Secang GTT-PTT Honorary Forum at Secang District, to provide training and mentoring for the preparation of CAR increasing the knowledge about CAR development. This community service was carried out within 4 months. This activity was attended by 25 participants. The method of activities carried out to resolve partner problems was through training and mentoring divided into 5 meetings at the SDN 2 Secang hall. Material presented at the first meeting were: (1) PTK concept; (2) preparation of background, problem identification and formulation of topics and problems; (3) looking for sources of reference related to the topic, as well as the design of the CAR implementation; (4) preparation of results and discussion; and (5) finalization of the report.
\end{abstract}

Keywords:Community Services, Training, Action Research

\begin{abstract}
Abstrak: Permenpan-RB Tahun 2009 tentang Pengembangan Keprofesian Berkelanjutan (PKB) tidak hanya ditujukan kepada guru PNS saja namun guru secara umum. Anggota Forum Tenaga Honorer GTT-PTT Kecamatan Secang memiliki keinginan yang kuat untuk mampu menyusun PTK. Namun, keinginan tersebut terkendala dengan terbatasnya kesempatan yang diberikan kepada mereka untuk mengikuti pelatihan PTK. Sebagian besar dari mereka tidak memiliki pengetahuan yang cukup mengenai penyusunan PTK. Selain awam dengan metode penelitian, mereka juga tidak memiliki pengetahuan tentang bagaimana merencanakan dan menyusun laporannya. Melihat masalah tersebut, kegiatan pengabdian ini menjadi upaya konkret dalam membantu guru terutama anggota Forum Tenaga Honorer GTT-PTT Kecamatan Secang untuk memberikan pelatihan dan pendampingan penyusunan PTK dalam meningkatkan pengetahuan tentang penyusunan PTK. Pengabdian masyarakat ini dilaksanakan dalam waktu 4 bulan. Kegiatan ini diikuti oleh 25 peserta. Metode kegiatan yang dilaksanakan guna menyelesaikan permasalahanmitra adalah dengan pelatihan dan pendampingan yang dibagi menjadi 5 pertemuan bertempat di aula SDN 2 Secang. Materi yang disampaikan dalam pertemuan pertama adalah: (1) konsep PTK; (2) penyusunan latar belakang, identifikasi masalah serta perumusan topik dan masalah; (3) mencari sumber rujukan terkait topik, serta desain pelaksanaan PTK; (4) penyusunan hasil dan pembahasan; dan (5) finalisasi laporan.
\end{abstract}

Kata kunci : Pengabdian Masyarakat, Pelatihan, Ptk 
Available online at https://jurnal.stmikroyal.ac.id/index.php/jurdimas

\section{PENDAHULUAN}

Pengembangan Keprofesian Berkelanjutan (PKB) dimaksudkan untuk meningkatkan profesionalitas guru melalui pengembangan diri, publikasi ilmiah, dan/ atau pengembangan karya inovatif (KemenpanRB, 2009). Melalui peraturan ini, guru diharapkan mampu meningkatkan profesionalitasnya baik melalui tugas pokoknya yakni mengajar dan membimbingng maupun kegitaan pendukung lainnya yang telah disebutkan di atas. Sebagai pedoman, pelaksanaan kegiatan yang dapat diajukan pada pengajuan penilaian beserta angka kreditnya telah tercantum dalam Kemendikbud (2019).

Peraturan tersebut tidak hanya ditujukan kepada guru PNS saja namun guru secara umum. Untuk kepentingan kepangkatan, peraturan terkait penilaian angka kredit memang lebih diperuntukkan kepada guru PNS. Namun tidak menutup kemungkinan komponen-komponen yang terdapat di dalamnya dilaksanakan oleh guru non-PNS.

Berdasarkan wawancara dengan pengurus Forum Tenaga Honorer GTT-PTT Kecamatan Secang Kabupaten Magelang, terkait diklat yang diselenggarakan oleh Dinas Pendiidkan dan Kebudayaan Kab. Magelang lebih banyak ditujukan oleh guru PNS. permasalahan prioritas yang disepakati untuk segera diselesaikan adalah meningkatkan kemampuan guru dalam menyusun Penelitian Tindakan Kelas. Hasil wawancara dengan salah satu pengurus Forum Tenaga Honorer GTT-PTT Kecamatan Secang pun mengindikasikan bahwa terbatasnya kesempatan untuk mengikuti pelatihan penyusunan PTK.

Melihat masalah tersebut, kegiatan pengabdian ini menjadi upaya konkret dalam membantu guru terutama anggota Forum Tenaga Honorer GTT-PTT Kecamatan Secang untuk memberikan pelatihan dan pendampingan penyusunan PTK untuk meningkatkan pengetahuan mereka akan penyusunan PTK. Forum Tenaga Honorer GTT-PTT khususnya Kecamatan Secang lalu mendorong pihak Dinas Pendidikan dan Kebudayaan Kab. Magelang untuk memberikan lebih banyak kesempatan kepada guru non-
PNS untuk memperoleh pendidikan dan pelatihan yang setara. Hasilnya, saat ini pihak Dinas melalui PGRI Kabupaten dan Kecamatan melibatkan guru honorer dalam kepanitiaan dan kegiatan yang diselenggarakan oleh dinas maupun PGRI.

Anggota Forum Tenaga Honorer GTT-PTT Kecamatan Secang yang memiliki keinginan yang kuat untuk mampu menyusun PTK, namun keinginan tersebut terkendala dengan terbatasnya kesempatan yang diberikan kepada mereka untuk mengikuti pelatihan PTK. Sebagian besar dari mereka tidak memiliki pengetahuan yang cukup mengenai penyusunan PTK. Selain awam dengan metode penelitian, mereka juga tidak memiliki pengetahuan tentang bagaimana merencanakan dan menyusun laporannya.

\section{METODE}

Pengabdian masyarakat ini dilaksanakan dalam waktu 4 bulan. Kegiatan ini ditargetkan akan diikuti oleh 25 peserta. Metode kegiatan yang dilaksanakan guna menyelesaikan permasalahanmitra adalah dengan pelatihan dan pendampingan yang dibagi menjadi 5 pertemuan bertempat di aula SDN 2 Secang. Materi yang akan disampaikan dalam pertemuan pertama adalah: (1) konsep PTK; (2) penyusunan latar belakang, identifikasi masalah serta perumusan topik dan masalah; (3) mencari sumber rujukan terkait topik, serta desain pelaksanaan PTK; (4) penyusunan hasil dan pembahasan; dan (5) finalisasi laporan.

\section{PEMBAHASAN}

Pelatihan penulisan penelitian tindakan kelas dilaksanakan melalui 5 kali pertemuan tatap muka dan 3 kali pendampingan. Kendala yang ditemui terkait penentuan waktu pelaksanaan dikarenakan peserta yang berasal dari beberapa sekolah yang memiliki agenda masing-masing, sehingga penentuan waktu sering berubah demi kelancaran dan suksesnya pelaksanaan pelatihan pada setiap 
Available online at https://jurnal.stmikroyal.ac.id/index.php/jurdimas

pertemuannya.

Pertemuan perta adilaksanakan pada tanggal 27 Juli 2019 di aula SDN 2 Secang. Pelatihan ini dilaksanakan melalui kegiatan penyuluhan terkait konsep PTK. Pada pertemuan pertama ini dihadiri oleh Kepala Sekolah SDN 2 Secang. Konsep PTK disajikan pertama kali agar peserta memahami konsep awal mengapa perlu dan bagaimana proses penelitian tindakan kelas dilakukan. Peserta banyak yang belum memahami tentang konsep PTK tersebut, dikarenakan terbatasnya kesempatan untuk mengikuti pelatihan serupa. Berikut merupakan foto dari kegiatan pertama.

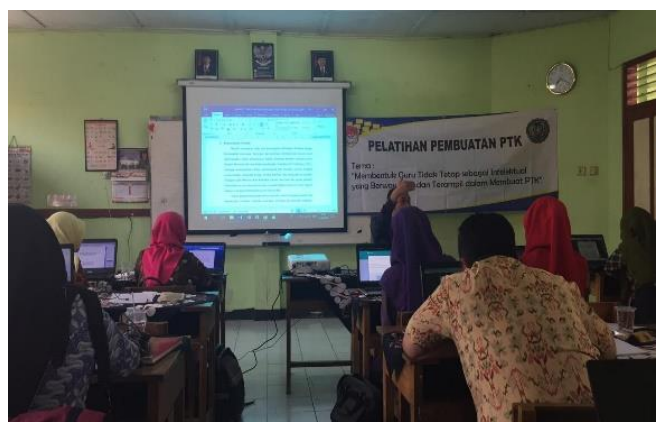

Gambar 4.1 Penyuluhan Konsep PTK

Materi yang disampaikan adalah terkait konsep dan sistematika penelitian tindakan kelas. Peserta berdiskusi mengenai bagaimana konsep penelitian tindakan kelas, mengapa perlu dilakukan penelitian tindakan kelas, dan bagaimana sistematika pembuatan penelitian tindakan kelas. Hal ini perlu pemahaman yang matang berhubung pemahaman konsep menjadi cikal bakal pembuatan penelitian tindakan kelas yang baik.

Pada pertemuan kedua, peserta diarahkan untuk mulai mencari permasalahan yang menjadi prioritas untuk dilakukan tindakan. Hampir semua peserta pernah membuat penelitian tindakan kelas, akan tetapi tidak semua benar-benar memahami konsep sehingga tidak berawal dari masalah yang harus diselesaikan akan tetapi memaksakan suatu model pada permasalahan tertentu. Pada kesempatan tersebut, diskusi degan peserta dilakukan untuk menemukan dan menentukan masalah yang harus segera dibenahi melalui penelitian tindakan kelas yang mereka lakukan.

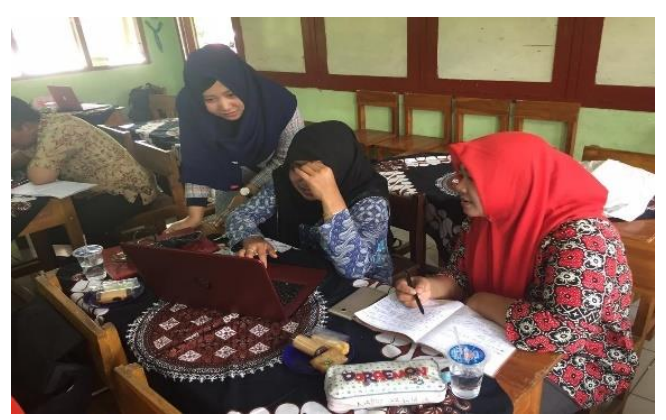

Gambar 4.2 Pelatihan Pembuatan

Latar Belakang

Pertemuan ketiga dilaksanakan pada tanggal 14 September 2019, di aula SDN 2 Secang. Tim pelaksana menyampaikan materi mengenai mencari sumber rujukan terkait topik, serta desain pelaksanaan PTK. Materi ini sangat perlu disampaikan karena hampir sebagian besar peserta belum mengetahui cara mencari dan mendapatkan rujukan yang tepat terkait penelitian yang akan mereka lakukan. Pada pertemuan ini, peserta juga dilatih membuat kutipan dan daftar pustaka otomatis. Sehingga, peserta dibiasakan untuk dapat menyusun daftar pustaka secara otomatis tanpa menyusun satu persatu karena sudah tersimpan dan terformat.

Sebelum pertemuan keempat dilaksanakan, pendampingan sebanyak dua kali dilakukan untuk membatu peserta dalam membuat proposal yang baik. Pendampingan dilaksanakan pada tanggal 21 September 2019 dan 28 September 2019. Kemudian, pertemuan keempat dilaksanakan pada tanggal 12 Oktober 2019. Pada pertemuan ini, tim pelaksana menyampaikan materi keempat, yaitu penyusunan hasil dan pembahasan. Pada pertemuan ini diskusi lebih banyak dilakukan. Peserta sangat antusias menyampaikan proses pelaksanaan penelitian, kendala dan juga hasil dari apa yang telah peserta lakukan. Pada pertemuan keempat ini, $85 \%$ peserta telah berproses melakukan penelitian tindakan kelas.

Pertemuan kelima merupakan pertemuan terakhir, dilaksanakan pada tanggal 30 Oktober 2019, peserta telah menyelesaikan rangkaian dan tahapan penelitian 
Available online at https://jurnal.stmikroyal.ac.id/index.php/jurdimas

tindakan kelas yang dilakukan. Finalisasi laporan telah selesai dilakukan. Dengan demikian, pelaksaaan pengabdian ini dapat dikatakan berhasil meningkatkan kemampuan guru dalam melakukan penelitian tindakan kelas.

\section{SIMPULAN}

Pelaksanaan kegiatan pengabdian telah terlaksana dengan baik dan sesuai dengan rencana. Tujuan dari kegiatan ini dapat tercapai dilihat dari meningkatnya pemahaman terkait penelitian tindakan kelas baik dari penyusunan, proses maupun finalisasinya. Setelah pelatihan ini peningkatan keterampilan juga terlihat terkait penggunaan reference manager. Dengan demikian secara keseluruhan kegiatan ini dikatakan berhasil.
Seluruh peserta menyambut baik dilaksanakannya kegiatan ini. Mereka berharap Tim Pelaksana dapat menyelenggarakan kegiatan serupa yang berkelanjutan. Hal ini sangat dirasakan manfaatnya oleh peserta karena mereka mendapat pemahaman berkaitan dengan penelitian tersebut. Selain itu, peserta terlihat semakin termotivasi untuk melakukan penelitian dan publikasi artikel ilmiah pada jurnal nasional.

\section{DAFTAR PUSTAKA}

Kemendikbud. (2019a). Buku 4 Pedoman Kegiatan Pengembangan Keprofesian Berkelanjutan dan Angka Kreditnya.

Kemendikbud. (2019b). Buku 5 Pedoman Penilaian Kegiatan Pengembangan Keprofesian Berkelanjutan.

Kemenpan-RB. Jabatan Fungsional Guru, Pub. L. No. 16 (2009). Indonesia. 